\title{
The Frequent Administrations of English Tests and High School Students' Anxiety, Motivation, Feelings and Final Achievement Test Scores
}

\author{
Mostafa Hosseyni Ramshe \\ Faculty of Foreign Languages, University of Isfahan, Isfahan 8174673441, Iran \\ Hossein Barati \\ Faculty of Foreign Languages, University of Isfahan, Isfahan 8174673441, Iran \\ Manijeh Youhanaee \\ Faculty of Foreign Languages, University of Isfahan, Isfahan 8174673441, Iran
}

\begin{abstract}
The purpose of this study was to explore the relationship between the frequent administrations of English tests and students' motivation, anxiety, and feelings. It also aimed to explore the effect of frequent administrations of English tests on students' scores on final achievement tests. Three groups of participants with frequent, semi-frequent, and no English tests during the study year participated in this study. A questionnaire was used so that the relationship between the frequent administrations of English tests and students' motivation, anxiety, and feelings could be addressed. The results of the study indicated that the frequent administrations of English tests would not decrease students' anxiety to a high degree. The study also revealed that only $\% 50$ of the students believed that their motivation would be promoted through frequent administration of English tests. In addition, the students in those high schools with the frequent administration of English tests did not show any progress compared with scores of the English tests of their preceding school year. Surprisingly, the high school with no test during the school year indicated that students have made significant progress when their tests scores of the preceding and the year under scrutiny were compared.
\end{abstract}

Index Terms - anxiety, feelings, motivation, frequent testing

\section{INTRODUCTION}

Every educational system entails an evaluative section to see whether the particular learners have met the ends of that system. This evaluation could take several forms. One of the instruments to measure students' attainments during a course is through paper and pencil tests. According to Bachman (1990) " a test is a measurement instrument designed to elicit a specific sample of an individuals' behavior" (p.20).

Sometimes, tests are frequently used as an instrument to facilitate students' learning. The notion behind the frequent administrations of tests is spaced or distributed practice method of memorization which Dempster (1988) refers to as "spacing effect". Spacing effect states that taking several tests, each of them covering a particular part of the material with a specific distance leads to a better learning than taking a test that includes all the material at once.

The effect of testing on teaching and learning in an educational system is referred to as "backwash" or "washback". Huges (2003) defines "backwash" as "the effect of testing on teaching and learning" and asserts that this effect can be either positive or negative (P.53). In positive washback well-designed tests are used as beneficial teaching and learning activities which lead to positive teaching and learning processes. On the other, hand in negative washback, taking a test will lead to the narrowing of the content of a particular course. So, students will only study those parts of the material which are directly related to that test and this changes the curriculum in a negative way.

Studies conducted on the role of frequent administrations of tests have investigated several aspects of it. Some of the studies investigated the effect of frequent administrations of tests on students' scores (e.g., Shirvani, 2009; Momeni \& Barinani, 2012; Gholami \& Moradi Moghaddam, 2013). These studies usually consisted of one experimental group with the frequent administrations of tests and one control group without it. The results of all of the previously mentioned studies showed an improvement in students' scores for the group with frequent tests. However, there are some studies like Deck (1998) in which this improvement was not significant.

Some other studies investigated the role of feedback which is given based on students' performance on these frequent tests. One of these studies is Marcell (2008). This study indicated that quizzes lead to more questions and comments at the beginning of the class and this feedback helps students to diagnose their weaknesses.

Moreover, there are other studies like Zarei (2010) which revealed that tests lead to fewer absences from the class.

Tests can also lead to the long-term retention of the material presented in the class (Butler \& Roediger, 2007). 
With regard to the effect of frequent tests on students' anxiety and motivation, studies like Yamin (1988) showed that frequent tests lead to less anxiety. In addition Hancock's study showed that test-anxious students were less motivated, when they were placed in a high-evaluative situation.

As these the results of these studies shows, several advantages have been mentioned for the frequent administrations of tests. In spite of all of these advantages, there are some studies like Deck (1988), Hancock (2001), and Basol \& Johanson's meta-analysis which indicated that frequent tests do not significantly affect students' motivation and scores significantly. So, more studies are needed to investigate such an effect.

There are many high schools in Iran which administer tests frequently as a part of their weekly program, and there are always opposing views on the role of these frequent tests in their syllabi. Students are always complaining about taking several tests during a school year and the anxiety which some of them experience before or during taking these frequent tests. There are some studies like Zarei (2010), Gholami \& Moradi Moghaddam (2013) and Momeni \& Barinani (2012) which investigated the effect of frequent administrations of English tests on EFL learners' scores on the next tests, but a study which investigates such an effect on students' anxiety, motivation, and feelings in a high school environment is rare. So, there seems to be a need to investigate the impact of such a pedagogical activity in high school classes. So, the first aim of this study was to examine whether the frequent administration of English tests made any significant difference on student's scores on their final achievement tests. The second aim was to investigate the relationship between the frequent administration of English tests and students' motivation, anxiety, and feelings.

\section{METHODOLOGY}

\section{Research Questions}

Research questions are presented here:

1. Is there any relationship between the frequent administration of English tests and the level of anxiety in EFL learners at Isfahan high schools?

2. Is there any relationship between the frequent administration of English tests and the level of motivation in EFL learners at Isfahan high schools?

3. How do high school EFL learners feel about the frequent administration of English tests?

4. Does the frequent administration of English tests make any significant difference in the performance of EFL learners at Isfahan high schools on their final achievement tests?

\section{Design}

This study enjoys an ex-post-facto design. Also, this study intends to see how the frequency of test administration relates to students' anxiety, motivation, and feelings and whether it makes any difference in students' scores on final achievement tests.

\section{Participants}

The participants of this study consisted of six intact classes which were selected from three groups of high schools. The schools were categorized in terms of the number of times they administered English tests to their students during the year. The school groups were as follows: frequently administering English tests: Edalat (52 students) and Etrat Sepahan (16 students). Semi-frequently administering English tests: Imam Sadegh (43 students). 3. No English test administration: Shahid Kazemi (33 students). I only used the scores of the students in Shahid Kazemi high school and they did not complete the questionnaire. The total number of the students contributed to this study was therefore 144 . Table 1 presents the specification of the participants in more details.

TABLE 1.

THE SPECIFICATION OF THE PARTICIPANTS OF THE STUDY

\begin{tabular}{|l|l|c|c|c|}
\hline High School & $\begin{array}{l}\text { Number of Times English } \\
\text { Tests Administered }\end{array}$ & Gender & Number & Year of High School \\
\hline Edalat & $\begin{array}{l}\text { Frequently } \\
(7-10 \text { tests during the year) }\end{array}$ & Female & 52 & Second Year \\
\hline Etrat Sepahan & $\begin{array}{l}\text { Frequently } \\
(7-10 \text { tests during the year })\end{array}$ & Female & 16 & Second Year \\
\hline Total & $\mathbf{6 8}$ & Male & 43 & Second Year \\
\hline Imam Sadegh & $\begin{array}{l}\text { Semi-Frequently } \\
(4-6 \text { tests during the year) }\end{array}$ & \multicolumn{1}{|c|}{ Second Year } \\
\hline Total & $\mathbf{4 3}$ & Male & 33 & \\
\hline Shahid Kazemi & No Test & & \\
\hline Total & $\mathbf{3 3}$ & $\mathbf{1 4 4}$ \\
\hline Total &
\end{tabular}

\section{Instruments}

The data for this study were collected in two ways: there was one questionnaire which was developed following a few interview sessions with one teacher and the students by the researcher. The scores of final achievement English tests in the second semester of the first and second year of high school were also used.

Questionnaire 
In order to construct the questionnaire, three students from one private high school (Imam Sadegh) with semifrequent administration of English tests in their second year of high school were interviewed. Also one English teacher from the same school was asked to participate in the interview sessions of the study. In these interviews the following questions were asked:

1. What do you think about taking frequent English tests during the term?

2. Express your feelings during taking these frequent English tests.

3. What effects do these frequent English tests have on the next tests and the final exam?

4. What is the effect of these frequent English tests on your motivation to study?

To avoid any misunderstanding, the questions were posed in Persian in all interview sessions. All the interview data were fully recorded, carefully transcribed, and analyzed so that the items of the questionnaire could be developed. These items were in relation to the frequency of test administration on the one side and the level of anxiety and motivation on the other.

According to the interviews with the students, three clusters of items were established for the questionnaire and then the questionnaire was given to three expert judges to decide whether the items of the questionnaire were related to those clusters. Table 2 shows the number of items in each cluster.

TABLE 2.

THE NUMBER OF ITEMS FOR EACH OF THE CLUSTERS OF QUESTIONNAIRE ITEMS

\begin{tabular}{|l|l|}
\hline Item Specification & Number of Item \\
\hline 1.The effect of frequent administration of English tests on anxiety & $1,3,7,10,11,12,13,17$ \\
\hline 2.The effect of frequent administration of English tests on motivation & $2,8,14,6$ \\
\hline 3. Students' feelings with regard to the frequent administration of English tests & $4,5,9,15,16,18,19,20$ \\
\hline Total & $\mathbf{2 0}$ \\
\hline
\end{tabular}

\section{Final Achievement Tests}

In order to measure whether the frequent administration of English tests made any significant difference in students' scores on their final achievement tests in the second year of high school, the scores of the students on their final achievement tests in the second semester of their first and second year of high school were used.

\section{Pilot Study}

In order to deal with issues like appropriateness of the instrument, timing, reliability, and ambiguity of items, the questionnaire was piloted with a group of high school students parallel to the participants of the study.

\section{Appropriateness of the Instrument}

Before the pilot study, some consultation with one professor with $\mathrm{Ph} . \mathrm{D}$. degree in applied linguistics from university of Isfahan and two English teachers with B.A degree in English language from two private high schools in Isfahan was done and based on this consultation, some modifications in the items were made.

Timing

The questionnaire was piloted with a group of 20 high school students which were parallel to the subjects in the study. It took 15 minutes for the students to complete the questionnaire.

\section{Reliability}

The pilot study produced a reliability of .798 which is relatively acceptable.

\section{Ambiguity of Items}

Some students experienced some difficulty with the heading of the questionnaire and they did not know what kind of tests it means. Based on what students said, some modifications in the heading of the questionnaire were made.

\section{Procedure for the Analysis of the Instruments}

In order to answer the first, second, and third questions, a Likert scale was used for the options of the questionnaire. Note that in all of the tables of the next chapter, SA stands for strongly agree, A for agree, SD for strongly disagree, and $\mathrm{D}$ for disagree. In the analysis, the numbers 4,3,0,2 and 1 were assigned to strongly agree, agree, neutral, disagree, and strongly disagree respectively. The column related to mean in each table indicates the mean of these numbers for each item. For items $7,9,10,11,12$, and 15 which were negative, the assignment of these numbers was reverse. The percentage of each of the options of the questionnaire for each item was also shown.

In order to investigate whether the frequent administration of English tests made any significant difference in students' scores on their final achievement tests, the scores of the students on their final achievement tests in the second semester of their first and second year of high school were used to see whether the frequent administration of English tests in the second year of high school made any difference in students' scores based on their scores in the first year of high school.

\section{DATA ANALYSIS}

\section{Research Questions}

Question One

Is there any relationship between the frequent administration of English tests and the level of anxiety in EFL learners at Isfahan high schools? 
Table 3 shows the mean of the total score of the boys' questionnaire. According to the procedure used to assign numbers to each of the options of the questionnaire, when someone chooses the option "strongly agree" for all of the items, the total score of that person is 80 .

TABLE 3.

DESCRIPTIVE STATISTICS FOR THE TOTAL SCORE OF THE BOYS' QUESTIONNAIRE

\begin{tabular}{|l|l|l|l|l|l|}
\hline & N & Minimum & Maximum & Mean & Std. Deviation \\
\hline SUM & 43 & 5.00 & 64.00 & 42.2093 & 11.19430 \\
Valid N (listwise) & 43 & & & & \\
\hline
\end{tabular}

As the table 3 shows, the mean of the total score of the boys' questionnaire was 42.20. It shows a degree of agreement with the frequent administration of English tests which is neither low nor high.

Table 4 also shows the mean of the total score of the girls' questionnaire.

TABLE 4.

DESCRIPTIVE STATISTICS FOR THE TOTAL SCORE OF THE GIRLS' QUESTIONNAIRE

\begin{tabular}{|l|l|l|l|l|l|}
\hline & N & Minimum & Maximum & Mean & Std. Deviation \\
\hline SUM & 68 & 22.00 & 62.00 & 39.3382 & 9.04320 \\
Valid N (listwise) & 68 & & & & \\
\hline
\end{tabular}

As the table 4 shows, the mean of the total score of the girls' questionnaire was 39.33. Like the boys' questionnaire, it shows a degree of agreement with the frequent administration of English tests which is neither low nor high.

Table 5 shows the mean of the degree of agreement or disagreement with items related to the factors which either increase students' anxiety or decrease it.

TABLE 5.

THE MEAN SCORE FOR THE PERCENTAGE OF AGREEMENT OR DIS AGREEMENT WITH ANXIETy ITEMS

\begin{tabular}{|l|l|l|l|l|l|l|}
\hline \multicolumn{2}{|l|}{} & SA+A & \multicolumn{2}{l|}{ SD+D } & \multicolumn{2}{l|}{ Mean } \\
\cline { 2 - 7 } & Boys & Girls & Boys & Girls & Boys \\
\hline $\begin{array}{l}\text { Factors that increase the anxiety of the } \\
\text { students }\end{array}$ & $\% 67.42$ & $\% 65.05$ & $\% 13.2$ & $\% 9.92$ & 1.73 & \multicolumn{1}{l|}{ Girls } \\
\hline $\begin{array}{l}\text { Factors that decrease the anxiety of the } \\
\text { students }\end{array}$ & $\% 61.8$ & $\% 69.15$ & $\% 16.85$ & $\% 13.6$ & 3.10 & 3.08 \\
\hline
\end{tabular}

As the table 5 shows, the mean of the degree of agreement with the factors which decrease students' anxiety was 61.8 for the boys and \%69.15 for the girls. Also, the mean of the degree of agreement with the factors that increase students' anxiety was $\% 67.42$ for the boys and $\% 65.05$ for the girls.

Table 6 shows the degree of agreement or disagreement with items which were related to anxiety.

TABLE 6.

THE PERCENTAGE OF AGREEMENT OR DiSAGREEMENT WITH ANXIETY ITEMS

\begin{tabular}{|c|c|c|c|c|c|c|}
\hline & \multicolumn{2}{|l|}{$\mathrm{SA}+\mathrm{A}$} & \multicolumn{2}{|l|}{ SD+D } & \multicolumn{2}{|l|}{ Mean } \\
\hline & Boys & Girls & Boys & Girls & Boys & Girls \\
\hline $\begin{array}{l}\text { 1. These tests will make me less anxious on the next } \\
\text { tests and the final achievement test. }\end{array}$ & $\% 58.2$ & $\% 50.1$ & $\% 27.9$ & $\% 25.0$ & 2.75 & 2.76 \\
\hline $\begin{array}{l}\text { 3. Studying more before the test will make me less } \\
\text { anxious during taking a test. }\end{array}$ & $\% 79.1$ & $\% 80.9$ & $\% 11.6$ & $\% 10.3$ & 3.17 & 3.20 \\
\hline $\begin{array}{l}\text { 7. Knowing that the scores of these tests will enter my } \\
\text { report card will increase my anxiety. }\end{array}$ & $\% 88.4$ & $\% 80.9$ & $\% 2.3$ & $\% 2.9$ & 1.33 & 1.35 \\
\hline $\begin{array}{l}\text { 10. Getting a low score on one test will increase my } \\
\text { anxiety on the next tests. }\end{array}$ & $\% 74.4$ & $\% 79.4$ & $\% 14.0$ & $\% 7.4$ & 1.81 & 1.69 \\
\hline $\begin{array}{l}\text { 11. The probability of the existence of subtle points } \\
\text { on the test will increase my anxiety. }\end{array}$ & $\% 69.7$ & $\% 63.2$ & $\% 18.6$ & $\% 11.8$ & 1.97 & 1.69 \\
\hline $\begin{array}{l}\text { 12. The feeling of competition which arises from } \\
\text { these tests will increase my anxiety. }\end{array}$ & $\% 37.2$ & $\% 36.7$ & $\% 27.9$ & $\% 17.6$ & 2.20 & 2.12 \\
\hline $\begin{array}{l}\text { 13. Getting a high score on these tests will decrease } \\
\text { my anxiety on the next tests and the final exam. }\end{array}$ & $\% 74.4$ & $\% 91.2$ & $\% 9.3$ & $\% 0$ & 3.22 & 3.40 \\
\hline $\begin{array}{l}\text { 17. Providing the answers of these tests will decrease } \\
\text { my anxiety on the next tests and the final exam. }\end{array}$ & $\% 53.5$ & $\% 54.4$ & $\% 18.6$ & $\% 19.1$ & 2.83 & 2.96 \\
\hline
\end{tabular}

Eight items in this questionnaire were related to anxiety which were examined in both girls and boys (Table 6).

Item 1 in this questionnaire was specifically related to question one. As the table 6 shows, \%58.2 of the boys and $\% 50.1$ of the girls agreed that these tests would decrease their anxiety on the next tests and the final achievement test and $\% 27.9$ of the boys and $\% 25$ of the girls disagreed with this item which is relatively considerable. This degree of disagreement shows that these tests did not decrease the anxiety of a large number of the students on the next tests and for some students the feeling of anxiety always existed. With regard to the factors which increase the anxiety of the students on the next tests and the final exam, 88.4 of the boys and \%80.9 of the girls agreed with the item stating, 
knowing that the scores of the tests would enter my report card would increase my anxiety, and this factor received the greatest degree of agreement. Also, \%74.4 of the boys and \%79.4 of the girls agreed that getting a low score on one test would increase their anxiety on the next tests. In addition \%69.7 of the boys and \%63.2 of the girls agreed that the probability of the existence of subtle points on the test would increase their anxiety. Moreover, \%37.2 of the boys and $\% 36.7$ of the girls agreed that the feeling of competition which might arise from these tests would increase their anxiety which was the lowest degree of agreement among all the questionnaire items.

There were also three other items in this questionnaire which considered the effect of factors which decrease the anxiety of the students. One of these factors was studying more before the test; \% 79.1 of the boys and \%80.9 of the girls agreed that this factor would decrease their anxiety, which shows that more study was an important factor in decreasing students' anxiety. Also, \%53.5 of the boys and \%54.4 of the girls agreed that providing the answers of the tests would decrease their anxiety on the next tests and the final exam which was the lowest degree of agreement among these factors. In addition $\% 74.4$ of the boys and \%91.2 of the girls agreed that getting a high score on one test would decrease their anxiety on the next tests.

To sum up, only about half of the students believed that these frequent tests would decrease their anxiety on the next tests.

\section{Question Two}

Is there any relationship between the frequent administration of English tests and the level of motivation in EFL learners at Isfahan high schools?

As the table 7 shows, the mean of the degree of agreement with the factors which increase students' motivation to study was \%56.97 for the boys and \%43.4 for the girls and it was not that much high.

TABLE 7.

THE PERCENTAGE of AgreEMENT OR DisAgreEMENT with Motivation ITEMS

\begin{tabular}{|c|c|c|c|c|c|c|}
\hline & \multicolumn{2}{|l|}{$\mathrm{SA}+\mathrm{A}$} & \multicolumn{2}{|l|}{$\mathrm{SD}+\mathrm{D}$} & \multicolumn{2}{|l|}{ Mean } \\
\hline & Boys & Girls & Boys & Girls & Boys & Girls \\
\hline $\begin{array}{l}\text { 2. These tests will make me more motivated to } \\
\text { study. }\end{array}$ & $\% 67.4$ & $\% 54.4$ & $\% 18.6$ & $\% 25$ & 2.78 & 2.72 \\
\hline $\begin{array}{l}\text { 6. The feeling of competition which may arise } \\
\text { from these tests will make me exert more } \\
\text { effort in my study. }\end{array}$ & $\% 55.9$ & $\% 55.9$ & $\% 18.6$ & $\% 20.6$ & 2.72 & 2.98 \\
\hline $\begin{array}{l}\text { 8. Knowing that the scores of these tests will } \\
\text { enter my report card will make me more } \\
\text { motivated to study. }\end{array}$ & $\% 48.8$ & $\% 22.1$ & $\% 30.2$ & $\% 44.1$ & 2.52 & 2.20 \\
\hline $\begin{array}{l}\text { 14. Getting a low score on one test will make } \\
\text { me more motivated to study for the next tests. }\end{array}$ & $\% 55.8$ & $\% 41.2$ & $\% 23.3$ & $\% 22.1$ & 2.79 & 2.72 \\
\hline Mean & $\% 56.97$ & $\% 43.4$ & $\% 22.67$ & $\% 27.95$ & 2.70 & 2.65 \\
\hline
\end{tabular}

Four items in this questionnaire were related to motivation.

Item 2 in the questionnaire was specifically related to question two and the three other items were related to the factors which increase the motivation of the students to study.

As the table 7 shows, \%67.4 of the boys and \%54.4 of the girls agreed that these tests would make them more motivated to study. Also \%18.6 of the boys and \%25 of the girls disagreed with this item. Like the previous question, this degree of agreement shows that frequent tests were motivating for about half of the students.

Regarding the factors which increase students' motivation to study, $\% 48.8$ of the boys and $\% 22.1$ of the girls agreed that knowing that the scores of these frequent tests would enter their report card would increase their motivation to study and \%55.8 of the boys and \%41.2 of the girls agreed that getting a low score on one test would increase their motivation to study.

Also, $\% 55.9$ of the boys and $\% 55.9$ of the girls agreed that the feeling of competition which might arise from these tests, would increase their motivation to study.

To conclude, more than half of the boys and about half of the girls believed that these frequent tests would make them more motivated to study.

\section{Question Three}

How do EFL learners feel about the frequent administration of English tests?

Table 8 shows the degree of agreement or disagreement with the items which were related to the positive feelings of the students about tests. 
TABLE 8.

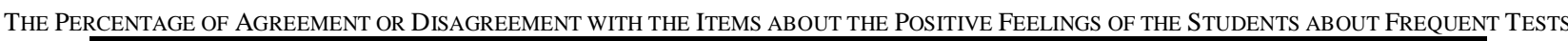

\begin{tabular}{|c|c|c|c|c|c|c|}
\hline & \multicolumn{2}{|l|}{$\mathrm{SA}+\mathrm{A}$} & \multicolumn{2}{|l|}{$\mathrm{SD}+\mathrm{D}$} & \multicolumn{2}{|l|}{ Mean } \\
\hline & Boys & Girls & Boys & Girls & Boys & Girls \\
\hline $\begin{array}{l}\text { 4. These tests will help me to } \\
\text { remember the material for a longer } \\
\text { time. }\end{array}$ & $\% 67.5$ & $\% 69.1$ & $\% 4.6$ & $\% 5.9$ & 3.22 & 3.21 \\
\hline $\begin{array}{l}5 \text {. These tests will create a feeling } \\
\text { of competition in me. }\end{array}$ & $\% 51.2$ & $\% 51.5$ & $\% 18.6$ & $\% 27.9$ & 2.67 & 2.92 \\
\hline $\begin{array}{l}\text { 18. These tests will help me to } \\
\text { become aware of my weaknesses. }\end{array}$ & $\% 72.1$ & $\% 75$ & $\% 16.3$ & $\% 5.9$ & 3.15 & 3.21 \\
\hline $\begin{array}{l}\text { 19. These tests will help me to } \\
\text { become of aware of those parts of } \\
\text { the book which are important for } \\
\text { the final exam. }\end{array}$ & $\% 72.1$ & $\% 77.9$ & $\% 14.0$ & $\% 4.4$ & 3.05 & 3.17 \\
\hline $\begin{array}{l}\text { 20. By taking these tests, I will need } \\
\text { less study for the final exam. }\end{array}$ & $\% 69.8$ & $\% 39.7$ & $\% 12.03$ & $\% 29.4$ & 2.91 & 2.46 \\
\hline $\begin{array}{l}\text { 16. Providing the answers of these } \\
\text { tests will help my learning. }\end{array}$ & $\% 67.5$ & $\% 69.1$ & $\% 4.7$ & $\% 7.4$ & 3.22 & 3.11 \\
\hline Mean & $\% 66.7$ & $\% 63.71$ & $\% 15.16$ & $\% 13.48$ & 3.03 & 3.01 \\
\hline
\end{tabular}

The mean of the degree of agreement with the items which considered the positive feelings of the students about tests was \%66.7 for the boys and \%63.71 for the girls (Table 8).

Five items in the questionnaire were related to the positive feelings of the students about tests. As the table 4.6 shows, \%67.5 of the boys and \%69.1 of the girls agreed that these tests would help them to remember the material for a longer time. Also, \%51.2 of the boys and \%51.5 of the girls agreed that frequent tests would create a feeling of competition in them which shows these tests did not create that much competition in the students. In addition, \% 72.1 of the boys and $\% 75$ of the girls believed that frequent tests would help them to become aware of their weaknesses. Moreover, \%72.1 of the boys and \%77.9 of the girls agreed that frequent tests would help them to become aware of those parts of the book which were important for the final achievement test. Needing less study for the final achievement test was another positive feeling of the students which received \%69.8 degree of agreement by the boys and $\% 39.7$ by the girls which shows regardless of the number of the tests, girls always studied much for the final achievement test. Finally, \%67.5 of the boys and \%69.1 of the girls agreed that providing the answers of these tests would help their learning.

Table 9 shows the degree of agreement and disagreement with the items which were related to the negative feelings of the students about tests.

TABLE 9.

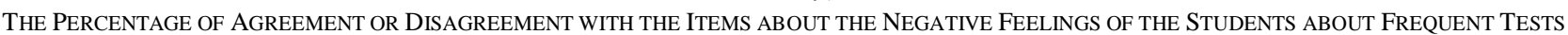

\begin{tabular}{|l|l|l|l|l|l|l|}
\hline \multicolumn{2}{|l}{} & SA+A & SD+D & Mean \\
\cline { 2 - 7 } & Boys & Girls & Boys & Girls & Boys & Girls \\
\hline $\begin{array}{l}\text { 9. Taking several tests during a } \\
\begin{array}{l}\text { week will create some problems } \\
\text { for other tests. }\end{array}\end{array}$ & $\% 95.3$ & $\% 82.3$ & $\% 2.3$ & $\% 7.4$ & 1.19 & 1.49 \\
\hline $\begin{array}{l}\text { 15. I am under the pressure of my } \\
\text { parents to study for these tests. }\end{array}$ & $\% 51.2$ & $\% 42.7$ & $\% 30.3$ & $\% 36.7$ & 2.20 & 2.53 \\
\hline Mean & $\% 73.25$ & $\% 62.5$ & $\% 16.3$ & $\% 22.05$ & 1.69 & 2.01 \\
\hline
\end{tabular}

To sum up, more than half of the boys and girls agreed with the positive and negative feelings which these tests might create for them.

As the table 9 shows, the mean of the degree of agreement with the factors which were related to the negative feelings of the students about frequent tests was \%73.25 for the boys and \%62.5 for the girls.

There were also two items which considered the negative feelings of the students about frequent tests. In one of these items, \%95.3 of the boys and \%82.3 of the girls agreed that taking several tests during a week would create some problems for other tests which was a large number. Also, \%51.2 of the boys and \%42.7 of the girls believed that they were under the pressure of their parents to study for these tests which shows parents did not create that much pressure for their students to study for these tests.

\section{Question Four}

Does the frequent administration of English tests make any significant difference in the performance of EFL learners at Isfahan high schools on their final achievement tests?

To answer this question the difference between students' scores on the final achievement tests in the second semester of their first and second year of high school in three groups of high schools with frequent administration of English tests, semi-frequent administration of English tests, and no English test during the year was computed.

First the difference between students' scores in two high schools with frequent administration of English tests was computed. 
TABLE 10.

T-TEST FOR FinAL ACHIEVEMENT TESTS 1 AND 2 IN Two High SCHOOLS WITH THE FREQUENT ADMINISTRATION OF ENGLISH TESTS.

\begin{tabular}{|c|c|c|c|c|c|c|}
\hline & \multirow[b]{2}{*}{$\mathrm{t}$} & \multirow[b]{2}{*}{ df } & \multirow[b]{2}{*}{ Sig. (2-tailed) } & \multirow[b]{2}{*}{ Mean Difference } & \multicolumn{2}{|c|}{$\begin{array}{l}95 \% \text { Confidence Interval of the } \\
\text { Difference }\end{array}$} \\
\hline & & & & & Lower & Upper \\
\hline Final Test 1 & 73.490 & 66 & .000 & 18.52612 & 18.0228 & 19.0294 \\
\hline Final Test 2 & 58.087 & 66 & .000 & 17.76493 & 17.1543 & 18.3755 \\
\hline
\end{tabular}

As the table 10 shows, the difference between students' scores on their final achievement tests in the second semester of their first and second year of high school was significant.

TABLE 11.

DESCRIPTIVE STATISTICS FOR FINAL ACHIEVEMENT TESTS 1 AND 2

\begin{tabular}{|l|l|l|l|l|}
\hline & N & Mean & Std. Deviation & Std. Error Mean \\
\hline Final Test 1 & 67 & 18.5261 & 2.06345 & .25209 \\
Final Test 2 & 67 & 17.7649 & 2.50336 & .30583 \\
\hline
\end{tabular}

But, as the table 11 shows, the students did not make any progress from the first year to the second year and the mean of the students' scores in their second year of high school was lower than the mean of the students' scores in their second year of high school.

The next category was one high school with semi-frequent administration of English tests. Table 12 shows the result of T-Test for this group of the participants.

TABLE 12.

T-TEST FOR FINAL ACHIEVEMENT TESTS 1 AND 2 In ONE HigH SCHOOL WITH SEMI-FREQUENT ADMINISTRATION OF ENGLISH TESTS

\begin{tabular}{|c|c|c|c|c|c|c|}
\hline & \multirow[b]{2}{*}{$\mathrm{t}$} & \multirow[b]{2}{*}{ df } & \multirow[b]{2}{*}{ Sig. (2-tailed) } & \multirow[b]{2}{*}{ Mean Difference } & \multicolumn{2}{|c|}{$\begin{array}{l}95 \% \text { Confidence Interval of the } \\
\text { Difference }\end{array}$} \\
\hline & & & & & Lower & Upper \\
\hline Final Test 1 & 276.277 & 42 & .000 & 19.57558 & 19.4326 & 19.7186 \\
\hline Final Test 2 & 110.548 & 42 & .000 & 18.91279 & 18.5675 & 19.2580 \\
\hline
\end{tabular}

As the table 12 shows, the difference between students' scores on the final achievement tests in the second semester of their first and second year of high school was significant.

TABLE 13.

DESCRIPTIVE STATISTICS FOR FINAL ACHIEVEMENT TESTS 1 AND 2 IN ONE HIGH SCHOOL WITH SEMI-FREQUENT ADMINISTRATION OF ENGLISH TESTS

\begin{tabular}{|l|l|l|l|l|}
\hline & $\mathrm{N}$ & Mean & Std. Deviation & Std. Error Mean \\
\hline Final Test 1 & 43 & 19.5756 & .46463 & .07085 \\
Final Test 2 & 43 & 18.9128 & 1.12187 & .17108 \\
\hline
\end{tabular}

But, again as the table 13 shows, there was no improvement in students' performance from the first year to the second year and the mean of the students' scores on the final achievement test 2 was lower than the final achievement test 1.

Finally, table 14 shows, the result of T-Test for students' scores on their final achievement tests in the second semester of their first and second year of high school in one high school without any test during the second year.

TABLE 14.

T-TEST FOR FINAL ACHIEVEMENT TESTS $1 \& 2$ IN ONE HIGH SCHOOL WITH NO TEST

\begin{tabular}{|c|c|c|c|c|c|c|}
\hline & \multirow[b]{2}{*}{$\mathrm{t}$} & \multirow[b]{2}{*}{ df } & \multirow[b]{2}{*}{ Sig. (2-tailed) } & \multirow[b]{2}{*}{ Mean Difference } & \multicolumn{2}{|c|}{$\begin{array}{l}\text { 95\% Confidence Interval of the } \\
\text { Difference }\end{array}$} \\
\hline & & & & & Lower & Upper \\
\hline Final Test 1 & 16.266 & 32 & .000 & 12.42424 & 10.8684 & 13.9801 \\
\hline Final Test 2 & 18.802 & 32 & .000 & 13.49242 & 12.0307 & 14.9542 \\
\hline
\end{tabular}

As the table 14 shows, the difference between students' scores on the final achievement tests in the second semester of their first and second year of high school was significant. 
TABLE15.

DESCRIPTIVE STATISTICS FOR FINAL ACHIEVEMENT TESTS $1 \& 2$ IN ONE High SCHOOL WITH NO TEST

\begin{tabular}{|l|l|l|l|l|}
\hline & $\mathrm{N}$ & Mean & Std. Deviation & Std. Error Mean \\
\hline Final Test 1 & 33 & 12.4242 & 4.38770 & .76380 \\
Final Test 2 & 33 & 13.4924 & 4.12239 & .71762 \\
\hline
\end{tabular}

As the table 15 shows, the mean of the students' scores on the final achievement test 2 was surprisingly higher than the mean of the students' scores on the final achievement test 1 and the students showed some progress in their scores in the second year compared with the first year.

\section{DiscUSSION}

\section{Question One}

Is there any relationship between the frequent administration of English tests and the level of anxiety in EFL learners at Isfahan high schools?

The analysis of the questionnaire revealed that about half of the boys and girls agreed that frequent tests would decrease their anxiety on the next tests and about one-third of them disagreed with it. This anxiety would increase to a high degree due to the factors such as knowing that the tests scores would enter students' report card and getting a low score on the previous tests. Also, half of the students believed that the probability of the existence of subtle points on the test would increase their anxiety. One of the justifications which can be given for such a finding is what students expressed in their interviews. They said that these tests might somehow lower their anxiety on the next tests, but taking a test would always bring some degree of anxiety for them. As, about half of the students believed that frequent test would decrease their anxiety on the next tests, the findings are in line with both the findings of Yamin (1988) which revealed that the group with frequent tests experienced less anxiety and also with the findings of Hancock (2001) which indicated high-evaluative situations led to more anxiety.

\section{Question Two}

Is there any relationship between the frequent administration of English tests and the level of motivation in EFL learners at Isfahan high schools?

Like the previous question frequent tests would increase students' motivation to study for more than half of the boys and about half of the girls. About half of the boys and less than half of the girls agreed that knowing that the scores of these tests would enter their report card and getting a low score on the previous tests would increase their motivation to study. This high degree of disagreement was perhaps due to this fact that it was not important for the students to take several tests during the term. For some students the time which they devoted to study was just the night before the exam, regardless of the number of the tests they took. As frequent tests increased the motivation of half of the students, this finding is in line with both the findings of William Deck (1998) which revealed that there was no difference between the study hours of those who took monthly tests and those with weekly tests and also with the findings of Hancock (2001) which showed that a high-evaluative condition led to less motivation.

\section{Question Three}

How do EFL learners feel about the frequent administration of English tests?

With regard to the items which were related to students' feelings, a high percentage of the boys and girls agreed that the frequent administration of English tests would help them to become aware of their weaknesses and also become aware of those parts of the book which were important for the final exam. Moreover, more than half of the boys and girls agreed that providing the answers of these tests would help their learning and these tests would help them to remember the material for a longer time. Also, about half of the boys and less than half of the girls agreed that by taking these tests, they would need less study for the final exam. In addition about half of the boys agreed that these tests would create a feeling of competition in them, but the degree of disagreement with the two last items was relatively high with respect to other items. Regarding the negative feelings of the students about frequent tests, a high percentage of them believed that taking several tests during a week would create some problems for other tests. In addition, being under the pressure of the parents to study for these tests was also another negative feeling which these tests may create for the students and it received the agreement of about half of the boys and less than half of the girls. The high percentage of disagreement by both boys and girls showed that parents were not that much concerned about these tests.

\section{Question Four}

Does the frequent administration of English tests make any significant difference in the performance of EFL learners at Isfahan high schools on their final achievement tests?

As the results showed, for those high schools with frequent and semi-frequent administration of English tests, the difference between students' scores on their final achievement tests of their first and second year of high school was significant but, the mean of the students' scores in their second year of high school was lower than their first year of high school and surprisingly higher for the high school without the frequent administration of English tests. So, as the analysis revealed, the students did not make any progress on their final achievement tests due to the frequent administration of English tests. These results are in contrast with studies like Shirvani (2009), Momeni \& Barinani (2012), Gholami \& Moradi Moghaddam (2013), Zarei (2010), Butler \& Roediger (2007), Yamin (1988), Dustin (1971), 
and Phelp's meta-analysis (2011) which showed that frequent tests led to a significant improvement in students' scores and in line with those studies like William Deck (1998), Dineen, Taylor \& Stephens (2010), and Basol's \& Johanson's meta-analysis (2009) which indicated that frequent tests did not lead to a significant improvement in students' scores.

\section{CONCLUSION}

Based on the above discussion some concluding remarks are drawn. As the results indicated, the frequent administration of English tests did not lead to an improvement in students' scores on their final achievement tests and surprisingly, as the study showed, the students without the frequent administration of English tests showed some progress in their final achievement tests' scores. In addition, frequent tests did not decrease the anxiety of a high percentage of the students and some degree of anxiety always existed in the students before or during taking a test. Moreover, frequent tests increased the motivation of about half of the students and they did not always lead to an increase in study hours. Finally, with respect to students' feelings about these tests, a high percentage of the students believed that these frequent tests would help them to become aware of their weaknesses and those parts of the book which are important for the final exam and also, taking several tests during a weak would create some problems for other tests.

\section{REFERENCES}

[1] Bachman, L. F. (1990). Fundamental considerations in language testing. New York: Oxford University Press.

[2] Basol, G., \& Johnson, G. (2009). Effectiveness of frequent testing over achievement: a meta-analysis study. International Journal of Human Sciences, 6(2), 99-120.

[3] Butler, A. C., Roediger, H. L. (2007). Testing improves long-term retention in a stimulated classroom setting. European Journal of Cognitive Psychology, 19(4/5), 514-527.

[4] Deck, D. W. (1998). The effects of frequency of testing on college students in a principles of marketing course. Retrieved November 2, 2013 from http://scholar.lib.vt.edu/theses/available/etd-110298-195932/unrestricted/dis.pdf.

[5] Dempster, F. N. (1988). The spacing effect: A case study in the failure to apply the results of psychological research. American Psychologist, 43(8), 627-634.

[6] Gholami, V., Morady Moghaddam, M. (2013). The effect of weekly quizzes on students' final achievement score. Modern Education and Computer Science, (1), 36-41.

[7] Hancock, D. R. (2001). Effects of test anxiety and evaluative threat on students' achievement and motivation. The Journal of Educational Research, 94(5), 284-290.

[8] Huges, A. (2003). Testing for language teachers. Cambridge: Cambridge University Press.

[9] Marcell, M. (2008). Effectiveness of regular online quizzing in increasing class participation and preparation. International Journal for the Scholarship of Teaching and Learning, 2(1), 1-9.

[10] Momeni, A., Barimani, Sh. (2012). The effect of testing frequency on Iranian pre-intermediate EFL learners' language achievement. Journal of Academic and Applied Studies, 2(10), 76-87.

[11] Shirvani, H. (2009). Examining an assessment strategy on high school mathematics achievement. American Secondary Education, 38(1), 34-45.

[12] Yamin, S.B. (1988). Frequency of testing and its effects on achievement in Chemistry, test anxiety, and attitudes toward science at University Technology of Malaysia. Retrieved November 1, 2013 from http://ir.library.oregonstate.edu/xmlui/bitstream/handle/1957/28982/YaminSulaimanBin1989.pdf?sequence=1.

[13] Zarei, A.A (2010).Course performance: the effect of quiz frequency on course performance and its relationship with class attendance of Iranian university learners of English. Journal of Persian Language and Literature, (26), 52-69.

Mostafa Hosseyni Ramshe was born in Ramshe, Isfahan city, on 6.6.1988. He received his B.A. in English translation studies from Isfahan University in 2011. He furthered his university studies on English education, and received his M.A. in TEFL from Isfahan University in 2013.

Hossein Barati works in the English department, University of Isfahan, where he is assistant Professor of Applied Linguistics. He has a PhD in „Language Testing" from University of Bristol and has been involved in research in language testing, programme evaluation, reading strategies, and classroom discourse. Before becoming a university lecturer in 1992, he worked as a language teacher at Ministry of Education, Isfahan, Iran.

Manijeh Youhanaee holds a PhD in language and linguistics from the University of Essex. She has co-authored with Badrizadeh "A Descriptive Dictionary of Theories of Generative Grammar". She has published a number of articles on the teaching/ acquisition of different English syntactic properties by native speakers of Persian. She teaches MA and PhD courses in linguistics, generative grammar, TEFL and SLA. Her areas of interest include syntactic theory, acquisition of L2 \& L3 syntax and issues in teaching and learning English as a second/foreign language. 